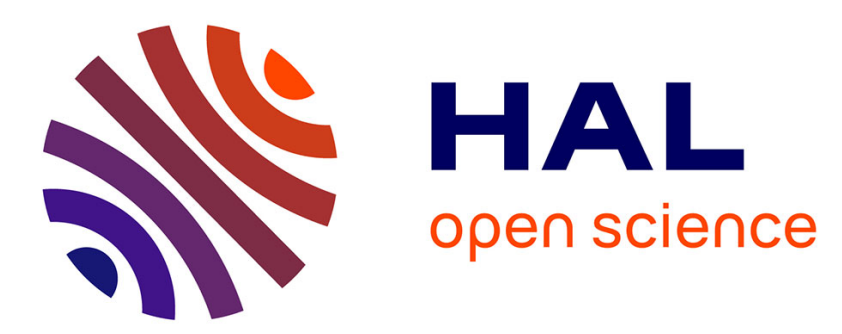

\title{
Photosynthetic assimilation and carbohydrate allocation of Quercus rubra seedlings in response to simulated herbivory
}

Phillip Woolery, Douglass Jacobs

\section{- To cite this version:}

Phillip Woolery, Douglass Jacobs. Photosynthetic assimilation and carbohydrate allocation of Quercus rubra seedlings in response to simulated herbivory. Annals of Forest Science, 2011, 68 (3), pp.617-624. 10.1007/s13595-011-0064-4 . hal-00930798

\section{HAL Id: hal-00930798 \\ https://hal.science/hal-00930798}

Submitted on 1 Jan 2011

HAL is a multi-disciplinary open access archive for the deposit and dissemination of scientific research documents, whether they are published or not. The documents may come from teaching and research institutions in France or abroad, or from public or private research centers.
L'archive ouverte pluridisciplinaire HAL, est destinée au dépôt et à la diffusion de documents scientifiques de niveau recherche, publiés ou non, émanant des établissements d'enseignement et de recherche français ou étrangers, des laboratoires publics ou privés. 


\title{
Photosynthetic assimilation and carbohydrate allocation of Quercus rubra seedlings in response to simulated herbivory
}

\author{
Phillip O. Woolery • Douglass F. Jacobs
}

Received: 5 July 2010 / Accepted: 6 November 2010 /Published online: 8 April 2011

(C) INRA and Springer Science+Business Media B.V. 2011

\begin{abstract}
- Introduction The artificial regeneration of oaks (Quercus spp.) can supplement deficient natural regeneration, yet growth and physiology of newly planted seedlings are often negatively affected by animal herbivory. Alternative nursery stock types with improved stress resistance may help improve regeneration success.

- Materials and method 1-year-old bare-root $(1+0)$ and container $(164 \mathrm{~mL})$ northern red oak (Quercus rubra L.) seedlings were transplanted into pots, subjected to two simulated browsing treatments (dormant or summer) or a non-browsed control, and grown for 18 weeks in a greenhouse.

- Results Although the container seedlings had 25\% higher photosynthetic rates compared to bare-root seedlings and greater proportional increases in biomass and total nonstructural carbohydrates (TNC), stock type differences to herbivory stress were deemed negligible based upon the absence of treatment interactions for any parameter. Summer browsing increased the rates of photosynthesis by $22 \%$, but whole-tree photosynthetic rates did not differ across browse treatments. Summer-browsed seedlings had lower lateral root biomass and severely depleted root TNC stores, resulting in a reduced whole-tree TNC content at final harvest; dormantbrowsed seedlings did not differ from control seedlings in photosynthetic rates, biomass, or TNC content.

- Conclusion Results suggest that, irrespective of stock type, dormant browsing has little impact on the morpho-
\end{abstract}

Handling Editor: Gilbert Aussenac

P. O. Woolery $\cdot$ D. F. Jacobs $(\bowtie)$

Department of Forestry and Natural Resources, Hardwood Tree

Improvement and Regeneration Center, Purdue University,

West Lafayette, IN 47907, USA

e-mail: djacobs@purdue.edu logical and physiological development of northern red oak seedlings, while summer browsing is highly detrimental.

Keywords Animal browse - Northern red oak .

Non-structural carbohydrates · Planting stock types .

Reforestation

\section{Introduction}

Landscape changes and elimination of predators have led to high populations of white-tailed deer (Odocoileus virginianus Zimmerman) in the Central Hardwoods Forest Region of the U.S., which have had severe negative impacts on the natural forest regeneration of some species, such as oaks (Quercus spp.) (Johnson et al. 2002). The impacts of herbivory on regeneration can be detrimental to resulting ecosystem composition and structure (Casabon and Pothier 2007; Horsley et al. 2003). The declining oak populations in this region associated with herbivory and land use changes have prompted an increased interest in the planting of these species, yet field establishment success is often limited (Dey et al. 2008; Jacobs et al. 2004).

Deer herbivory may alter seedling physiological status and growth responses variably depending upon the timing and severity of browse. Browse during dormancy removes the terminal bud, which releases apical dominance and stimulates lateral bud flushing (Cline 1997), often resulting in an increased leaf area. Oaks expend most of their stored non-structural carbohydrates (TNC) in the first flush (Kruger and Reich 1993), so regrowth of the leaf area after browsing of newly expanded leaves depends upon lower energy reserves (Carpenter et al. 2008). Following browsing, photosynthetic rates of both residual and new foliage 
are often higher (Kruger and Reich 1993; Tschaplinski and Blake 1989a). Altered photosynthetic rates may be a result of increased root to shoot ratios (Kruger and Reich 1993) or greater sink demand in storage tissues (Tschaplinski and Blake 1989b). Increased photosynthetic rates following browse may compensate for the loss of TNC during regrowth of the leaf area. For example, defoliation of poplars (Populus spp.) reduced TNC concentrations in roots but the trees recovered by the end of the growing season (Kosola et al. 2001). However, Kays and Canham (1991) found that TNC declined in saplings of various hardwood species that had shoots removed during the growing season.

In addition to the physiological changes, herbivory can affect seedling morphological development. Simulated browsing on silver birch (Betula pendula Roth) reduced leaf mass and overall growth (Berström and Danell 1995). The loss of leaf area can also lead to reductions in root growth through less fine root production and/or increased root mortality (Eissenstat and Duncan 1992; Ruess et al. 1998). Repeated browsing may result in prolonged stunted growth and/or mortality.

Seedling morphological and physiological quality, which is largely determined by nursery production practices, determines resistance to stresses such as herbivory (Burdett 1990). Bare-root nurseries efficiently produce large seedlings of northern red oak (Quercus rubra L.) and other hardwoods; however, the loss of fine roots and disruption of root-soil contact during lifting can adversely affect the physiological status after planting associated with reduced water potential, photosynthetic rates, and non-structural carbohydrates (Guehl et al. 1989, 1993; Jacobs et al. 2009). Additionally, oak seedlings exhibit rhythmic root and shoot growth, where root growth declines as shoot growth is maximized, and root growth is highest when shoot growth ceases (Reich et al. 1980; Willaume and Pages 2006). This pattern is a product of the balance of roots and shoots (Borchert 1975; Reich et al. 1980), which may be substantially altered by lifting of the bare-root seedlings. The reduced root size relative to the shoots of bare-root seedlings provides a plausible explanation for the minimal height growth (Andersen et al. 2000; Struve and Joly 1992) and die back (Johnson et al. 1984; Wilson et al. 2007) of bare-root seedlings that is often noted during the first season after planting, which persists until the balance is restored.

Container seedlings offer an alternative to bare-root stock types that may improve the resistance of northern red oak seedlings to herbivory and other stresses (Wilson et al. 2007). Because roots of container seedlings are protected by growing media, root loss is minimized during production and lifting (McKay 1996), which helps maintain root-soil contact and promotes fibrous root systems. The increased water and nutrient uptake associated with fibrous root systems (Blake and Sutton 1987; Irdis et al. 2004) explains improved water relations, higher photosynthetic rates, and accelerated growth rates frequently observed in container seedlings (Wilson et al. 2007; Zaczek et al. 1996). Both stored carbohydrates and current photosynthate contribute to new root proliferation in transplanted northern red oak seedlings (Sloan and Jacobs 2008). Because browsing inhibits new root growth (Eissenstat and Duncan 1992; Ruess et al. 1998), which limits photosynthesis and vice versa (Burdett 1990), the improved physiological status and greater root absorptive capacity of container seedlings following transplant may minimize the effects of herbivory stress on seedling development.

Despite the impact of herbivory on oak regeneration, relatively little research has examined interactions between timing of browse and seedling development during the critical field establishment phase. Furthermore, although container seedlings have shown potential to alleviate transplant stress and improve early field growth of northern red oak seedlings (Wilson et al. 2007), their capacity to specifically help reduce impacts of browsing stress has not been investigated. Thus, this study examined the effects of simulated browsing at varying seasonal periods (i.e., dormant vs. summer) for two common nursery stock types used in this region (i.e., $1+0$ bare-root or 164-ml container seedlings) on seedling growth and biomass allocation, TNC status, and photosynthetic assimilation. This knowledge is needed to improve understanding of the physiological impacts of herbivory on northern red oak seedlings, mechanisms that seedlings have evolved to resist browsing stress, and potential for alternative stock types to help alleviate impacts of herbivory. We hypothesized that (1) larger initial root to shoot, coupled with reduced transplant stress, of container seedlings (vs. bare-root stock) would lead to less expression of injury from herbivory associated with a more rapid ability to recover from incurred stresses, and (2) season of herbivory would create variable effects on seedling response to browse (based on timing of translocation of carbohydrate reserves), which would be most detrimental for summer-browsed bare-root stock due to the reliance of these seedlings mainly on stored reserves.

\section{Material and methods}

\subsection{Plant material}

The two experimental stock types were each grown from acorns collected from a stand of open pollinated trees located at the Indiana Department of Natural Resources State Tree Nursery near Vallonia, IN, USA $\left(38^{\circ} 48^{\prime} \mathrm{N}, 86^{\circ}\right.$ $\left.06^{\prime} \mathrm{W}\right)$. Container seedlings were sown in May 2008 into Styroblock $^{\mathrm{TM}}$ containers (Superblock 10, Beaver Plastics, Edmonton, AB, Canada) with a cavity volume of $164 \mathrm{ml}$, 
depth of $15.2 \mathrm{~cm}$, and a top diameter of $4.2 \mathrm{~cm}$, and operationally grown for 6 months at the University of Idaho Center for Forest Nursery and Seedling Research in Moscow, ID, USA $\left(41^{\circ} 43^{\prime} \mathrm{N}, 117^{\circ} 00^{\prime} \mathrm{W}\right)$ following methods similar to Wenny and Dumroese (1994). In November 2008, the seedlings were placed in storage at a temperature of approximately $1^{\circ} \mathrm{C}$. In early March 2009, they were shipped to Purdue University in West Lafayette, IN, USA $\left(40^{\circ} 25^{\prime} \mathrm{N}, 86^{\circ} 55^{\prime} \mathrm{W}\right)$ and stored at $3^{\circ} \mathrm{C}$ until transplanting. Bare-root seedlings were operationally grown (Jacobs 2003) for 1 year at a density of 48 seedlings per square meter at the Indiana Department of Natural Resources State Tree Nursery. They were lifted in December 2008 and stored in moist wood shavings at a temperature of $3.3^{\circ} \mathrm{C}$ until transplanting.

\subsection{Statistical design, treatments, and data analysis}

This study was a completely randomized design using a factorial treatment structure of two stock types and three levels of simulated browse. There were five seedlings per treatment combination for a total of 30 seedlings; the sampling unit was an individual seedling and the experimental unit was defined as the mean response of each treatment replicate. The seedlings were transplanted in early May 2009 into 12-L containers with a rooting medium consisting of peat, perlite, and sand in equal portions. Additionally, $45 \mathrm{~g}$ of controlled-release fertilizer (Osmocote $^{\circledR}$ Plus, NPK 15-9-12, with trace elements, The Scotts Company, Marysville, OH, USA) was uniformly incorporated into the medium. The potted seedlings were then randomly placed on a single greenhouse bench in the Horticulture and Landscape Architecture Plant Growth Facility at Purdue University and watered to saturation every 3-5 days during the course of the study.

The treatment levels for the simulated browse were based upon findings of Healy (1971) and Crawford (1982), who observed that the primary deer browsing periods on woody plants are during winter and late spring. Thus, the three simulated browse treatment levels were control (no browse), dormant browse, and summer browse. In the dormant browsing treatment, the terminal bud cluster of every main and lateral stem was removed (by clipping) during dormancy using hand clippers. To standardize the summer browsing treatment with seedling physiological status, the Quercus Morphological Index (QMI) was used. The QMI was developed by Hanson et al. (1986) to characterize specific stages of seedling growth. According to the QMI the 1-lag stage is longer than other stages in the first flush, so there is a higher likelihood that all of the stock types will simultaneously be in the 1-lag stage. The summer browsing treatment removed (clipped) $100 \%$ of the current year's growth at the 1-lag stage.
Data analyses were performed using analysis of variance (ANOVA) in SAS (version 9.1, SAS Institute Inc., Cary, NC, USA). Repeated measures ANOVA was used to analyze gas exchange data only. All models were tested for assumptions concerning normality, constant variance and linearity, with transformations applied as needed. Tests comparing treatment means were performed at $\alpha=0.05$ using Tukey's HSD conservative test.

\subsection{Measurements}

Prior to transplanting, a sample of 15 seedlings from each stock type was randomly selected to determine the initial seedling morphological and physiological conditions. Measurements of height, root collar diameter (RCD), root volume, first-order lateral roots (FOLR), and root to shoot ratio were performed. Additionally, the TNC were measured based on methods described by Chow and Landhausser (2004). Briefly, sugar was extracted from samples using hot ethanol, and starch was digested to glucose hydrolysate with $\alpha$-amylase/ amyloglucosidase enzyme solution. Concentrations of sugar and glucose hydrolysate were then determined with a spectrophotometer.

After transplanting, the seedling growth stages were monitored by measuring the shoot elongation and leaf expansion of the second to the last leaf from the top of the flush (Hanson et al. 1986). When the seedlings reached the 1lag stage, gas exchange (i.e., photosynthesis and transpiration) was measured at midday (1100-1400 hours) at near weekly intervals using a portable gas exchange analyzer (LI-6400, LICOR Biosciences, Lincoln, NE, USA). Chamber conditions were set to near ambient greenhouse conditions (block temperature $=25^{\circ} \mathrm{C}, \mathrm{CO}_{2}$ concentration $=375 \mu \mathrm{mol} \mathrm{mol}{ }^{-1}$, light $=400 \mu \mathrm{mol} \mathrm{m} \mathrm{m}^{-2} \mathrm{~s}^{-1}$, relative humidity $=70 \%$ ). Wholetree photosynthetic rates were calculated by expanding the last photosynthesis measurement to the destructively sampled seedling leaf area. Water use efficiency (WUE) was calculated as the ratio of assimilation to transpiration.

At the conclusion of the study in September 2009, all the seedlings were harvested and measured for height, RCD, root volume, FOLR, leaf area, and root to shoot ratio. The total nonstructural carbohydrates were also analyzed using the same methods as described in the analysis for the initial samples.

\section{Results}

\subsection{Initial seedling characterization}

At the time of transplant, bare-root seedlings were significantly larger than container seedlings $(P<0.0001)$ in height $(77 \%)$, RCD $(42 \%)$, root volume $(76 \%)$, FOLR (59\%), shoot dry weight (91\%), taproot dry weight $(82 \%)$, 
and lateral root dry weight $(60 \%)$ (Table 1). Container seedlings, however, had significantly $(P<0.0001)$ larger root to shoot ratios $(50 \%)$. Analysis of the TNC concentration ( $\mathrm{mg} / \mathrm{g}$ dry weight) showed no significant differences between the container and bare-root seedlings. Due to their greater biomass, bare-root seedlings had significantly $(P<0.0001)$ higher TNC content (Table 1).

\subsection{Gas exchange}

Photosynthetic rates through the growing season were significantly affected by stock type $(P=0.0009)$ and browse $(P=0.0150)$, though not by sampling time or any interaction between treatments. Container seedlings had photosynthetic rates that were $25 \%$ greater than bare-root seedlings (Fig. 1). Summer-browsed seedlings had the highest photosynthetic rates with a $17 \%$ and $24 \%$ increase over control and dormant-browsed seedlings, respectively (Fig. 1). Treatments did not differ significantly for WUE. Whole-tree photosynthetic rates at the end of the growing season were significantly affected by stock type $(P=0.0086)$ only. Whole-tree photosynthetic rates for bare-root seedlings were $48 \%$ greater than for container seedlings (Fig. 2).

\subsection{Final seedling characterization}

No seedling response variables at final harvest were significantly affected by treatment interactions. However, bare-root seedlings were significantly $(P<0.0001)$ larger than container seedlings in height $(72 \%), \mathrm{RCD}(27 \%)$, root volume $(68 \%)$, FOLR $(60 \%)$, leaf area $(47 \%)$, shoot dry weight $(62 \%)$, taproot dry weight $(73 \%)$, and lateral root dry weight (61\%) (Table 1). Consistent with initial characteristics, root to shoot ratios were higher in container seedlings $(44 \%)$. In regard to browsing treatments, control seedlings had significantly $(P<0.0001)$ greater lateral root dry weight $(33 \%)$ and root to shoot ratio $(77 \%)$ compared to summer-browsed seedlings (Table 2).

At final harvest, there were no significant differences in TNC concentration between stock types (Table 1) or among browse treatments (Table 2). TNC content, however, was significantly $(P<0.0001)$ influenced by stock type, with bare-root seedlings having 367\% higher TNC content than container seedlings (Table 1). TNC content was also significantly $(P=0.0114)$ influenced by browse treatment; unclipped control seedlings had $90 \%$ greater TNC content than summer-browsed seedlings (Table 2).

Container seedlings had the largest mean percent increases in height, RCD, root volume, FOLR, shoot dry weight, taproot dry weight, and TNC of all components (shoot, taproot, lateral root, and whole tree) compared to the initial sample (Table 3). Summer-browsed seedlings had the lowest mean percent increases in all morphological characteristics and TNC of all the components compared to the initial sample (Table 4). Notably, the percentage increases of TNC in tap and lateral roots were negative for summer-browsed seedlings (Table 4).

Table 1 Mean $( \pm 95 \%$ CL) HT, RCD, RV, number of FOLR, LA, SDW, TRDW, LRDW, R:SDW, and whole-tree concentration and content of TNC at time of planting (initial measurements) and at harvest (final measurements) for stock type treatments (container and bare-root seedlings)

\begin{tabular}{|c|c|c|c|c|}
\hline & \multicolumn{2}{|c|}{ Initial measurements } & \multicolumn{2}{|c|}{ Final measurements } \\
\hline & Container & Bare-root & Container & Bare-root \\
\hline $\mathrm{HT}(\mathrm{cm})$ & $16 \pm 11 \mathrm{~b}$ & $66 \pm 11 \mathrm{a}$ & $23 \pm 13 b$ & $81 \pm 13$ a \\
\hline $\mathrm{RCD}(\mathrm{mm})$ & $4.0 \pm 1.1 \mathrm{~b}$ & $7.0 \pm 1.1 \mathrm{a}$ & $6.8 \pm 1.5 \mathrm{~b}$ & $9.4 \pm 1.5 \mathrm{a}$ \\
\hline $\mathrm{RV}\left(\mathrm{cm}^{3}\right)$ & $5.5 \pm 3.3 \mathrm{~b}^{\mathrm{a}}$ & $22.9 \pm 6.6 \mathrm{a}^{\mathrm{a}}$ & $18 \pm 19 b$ & $56 \pm 19 \mathrm{a}$ \\
\hline FOLR & $1.7 \pm 2.1 \mathrm{~b}$ & $4.1 \pm 2.1 \mathrm{a}$ & $3.6 \pm 5.1 \mathrm{~b}$ & $9.0 \pm 5.1 \mathrm{a}$ \\
\hline LA $\left(\mathrm{cm}^{2}\right)$ & $-^{\mathrm{b}}$ & $-^{\mathrm{b}}$ & $334 \pm 246 \mathrm{~b}$ & $633 \pm 246 \mathrm{a}$ \\
\hline SDW (g) & $0.6 \pm 0.6 b^{a}$ & $6.6 \pm 0.9 \mathrm{a}^{\mathrm{a}}$ & $2.0 \pm 1.5 \mathrm{~b}^{\mathrm{a}}$ & $12.9 \pm 4.0 \mathrm{a}^{\mathrm{a}}$ \\
\hline TRDW (g) & $2.2 \pm 2.5 \mathrm{~b}$ & $12.1 \pm 2.6 \mathrm{a}$ & $4.9 \pm 5.6 \mathrm{~b}$ & $17.9 \pm 5.6 \mathrm{a}$ \\
\hline LRDW (g) & $0.3 \pm 0.3 \mathrm{~b}$ & $0.8 \pm 0.3 \mathrm{a}$ & $1.0 \pm 1.3 \mathrm{~b}^{\mathrm{a}}$ & $2.7 \pm 2.1 \mathrm{a}^{\mathrm{a}}$ \\
\hline R:SDW & $4.0 \pm 0.9 \mathrm{a}$ & $2.0 \pm 0.8 \mathrm{~b}$ & $2.9 \pm 0.7 \mathrm{a}$ & $1.6 \pm 0.7 \mathrm{~b}$ \\
\hline $\mathrm{TNC}\left(\mathrm{mg} \mathrm{g}^{-1}\right)$ & $158 \pm 31 \mathrm{a}$ & $145 \pm 31 \mathrm{a}$ & $105 \pm 24 \mathrm{a}$ & $100 \pm 24 \mathrm{a}$ \\
\hline TNC (mg) & $540 \pm 696 \mathrm{~b}$ & $2,850 \pm 696 \mathrm{a}$ & $1,105 \pm 1,165 \mathrm{~b}$ & $4,057 \pm 1,209 \mathrm{a}$ \\
\hline
\end{tabular}

Different letters indicate significant treatment differences at $\alpha=0.05$ across stock type treatments within a sampling period

$C L$ confidence level, $H T$ height, $R V$ root volume, $L A$ leave area, $S D W$ shoot dry weight, TRDW taproot dry weight, $L R D W$ lateral root dry weight, $R: S D W$ root to shoot dry weight ratio

${ }^{\mathrm{a}}$ Values were back transformed

${ }^{\mathrm{b}}$ Values were not determined 


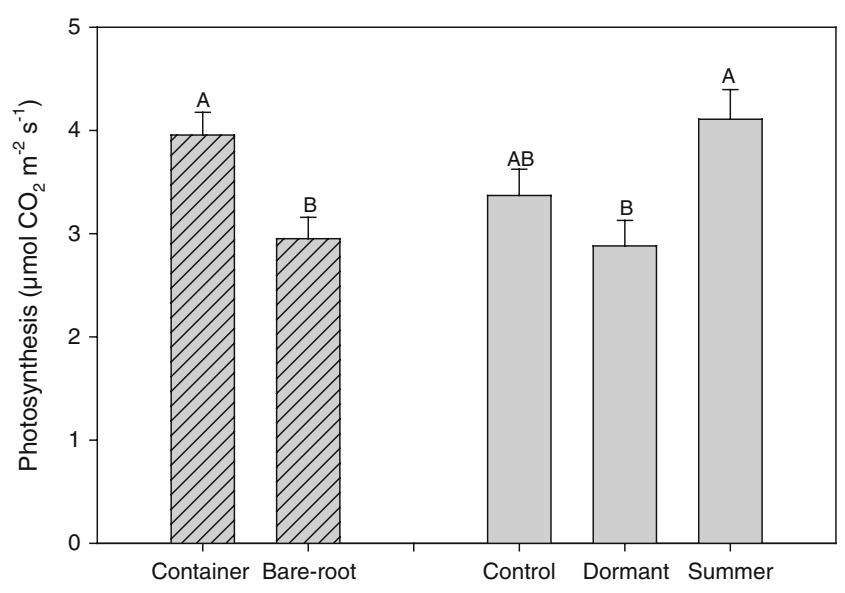

Fig. 1 Photosynthetic rates of seedlings 1, 2, 5, and 6 weeks after reaching lag-1 stage for stock type (lined bars) and browse (solid bars) treatments. Bars represent treatment means pooled from the four measurement points and error bars represent standard errors. For either stock type or browse, different letters indicate significant differences at $\alpha=0.05$

\section{Discussion}

\subsection{Nursery stock type responses}

Bare-root seedlings had greater biomass and TNC content than container seedlings at the initiation and end of the study (Table 1), although container seedlings had higher mean percent increases for these parameters (Table 3 ). We also observed higher gas exchange rates of container vs. bare-root seedlings (Fig. 1). With greater proportions of fine and lateral roots, container seedlings had increased water absorption capacity, which improved $\mathrm{CO}_{2}$ assimilation rates (Kruger and Reich 1993).

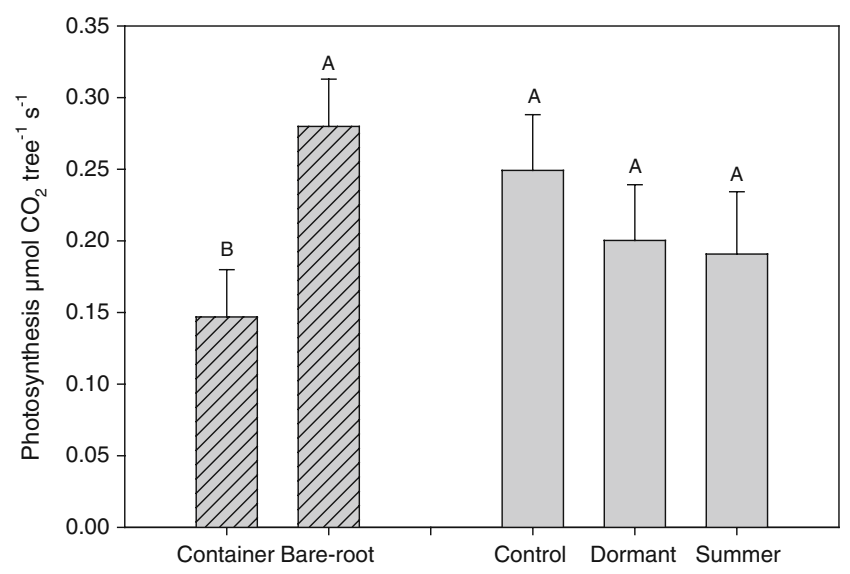

Fig. 2 Whole-tree photosynthetic rates determined from photosynthesis measurements taken 6 weeks after reaching lag-1 stage for stock type (lined bars) and browse (solid bars) treatments. Bars represent standard errors. For either stock type or browse, different letters indicate significant differences at $\alpha=0.05$
Table 2 Mean $( \pm 95 \%$ CL) HT, RCD, RV, number of FOLR, SDW, TRDW, LRDW, R:SDW, and whole-tree concentration and content of TNC at harvest (final measurements) for seedlings subjected to three simulated browse treatments (control, dormant, and summer)

\begin{tabular}{|c|c|c|c|}
\hline & \multicolumn{3}{|c|}{ Browsing treatment } \\
\hline & Control & Dormant & Summer \\
\hline HT (cm) & $55 \pm 16$ a & $55 \pm 15$ a & $46 \pm 16 \mathrm{a}$ \\
\hline $\mathrm{RCD}(\mathrm{mm})$ & $8.5 \pm 1.8 \mathrm{a}$ & $8.5 \pm 1.8 \mathrm{a}$ & $7.4 \pm 1.8 \mathrm{a}$ \\
\hline $\mathrm{RV}\left(\mathrm{cm}^{3}\right)^{\mathrm{a}}$ & $44 \pm 24 \mathrm{a}$ & $42 \pm 24 \mathrm{a}$ & $26 \pm 24 \mathrm{a}$ \\
\hline FOLR & $7.7 \pm 6.3 \mathrm{a}$ & $7.0 \pm 6.0 \mathrm{a}$ & $4.0 \pm 6.4 \mathrm{a}$ \\
\hline LA $\left(\mathrm{cm}^{2}\right)$ & $524 \pm 307 \mathrm{a}$ & $577 \pm 290 \mathrm{a}$ & $349 \pm 307 \mathrm{a}$ \\
\hline $\operatorname{SDW}(g)^{a}$ & $6.9 \pm 3.5 \mathrm{a}$ & $7.0 \pm 3.5 \mathrm{a}$ & $4.9 \pm 3.0 \mathrm{a}$ \\
\hline TRDW (g) & $13.1 \pm 7.1 \mathrm{a}$ & $12.5 \pm 6.7 \mathrm{a}$ & $8.6 \pm 7.1 \mathrm{a}$ \\
\hline $\operatorname{LRDW}(\mathrm{g})^{\mathrm{a}}$ & $3.0 \pm 2.8 \mathrm{a}$ & $1.7 \pm 2.0 \mathrm{ab}$ & $1.0 \pm 2.0 \mathrm{~b}$ \\
\hline R:SDW & $2.6 \pm 0.9 \mathrm{a}$ & $2.1 \pm 0.9 \mathrm{ab}$ & $2.0 \pm 0.9 \mathrm{~b}$ \\
\hline $\mathrm{TNC}\left(\mathrm{mg} \mathrm{g}^{-1}\right)$ & $107 \pm 30 \mathrm{a}$ & $100 \pm 30 \mathrm{a}$ & $100 \pm 30 \mathrm{a}$ \\
\hline TNC (mg) & $3,136 \pm 1,452 \mathrm{a}$ & $2,877 \pm 1,452 \mathrm{a}$ & $1,730 \pm 1,452 b$ \\
\hline
\end{tabular}

Different letters indicate significant differences across browsing treatments at $\alpha=0.05$

$C L$ confidence level, $H T$ height, $R V$ root volume, $S D W$ shoot dry weight, $T R D W$ taproot dry weight, $L R D W$ lateral root dry weight, $R$ : $S D W$ root to shoot dry weight ratio

${ }^{\text {a }}$ Values were back transformed

More rapid early growth rates of container compared to bare-root seedlings have been observed previously for northern red oak (Johnson et al. 1984; Wilson et al. 2007). In our case, however, although container stock grew more relative to original size, as is typical with seedlings of variable initial size (see van den Driessche 1992 and references therein), absolute growth was greater for bareroot seedlings (e.g., 6.3 vs. $1.4 \mathrm{~g}$ in shoot dry weight, Table 1). Additionally, bare-root seedlings had higher whole-tree photosynthetic rates associated with increased leaf area (Fig. 2) and no differences were detected in WUE. Thus, our data does not support evidence for reduced transplant stress of container seedlings under the present study conditions (i.e., well watered and subjected to variable browsing treatments). Furthermore, the lack of treatment interactions for any of the tested parameters suggests stock type responses to browsing are similar. Responses may vary, however, when seedlings are exposed to moderate or severe drought under field conditions.

\subsection{Influences of simulated herbivory}

Summer-browsed seedlings were generally smaller than control and dormant-browsed seedlings at the final harvest; they had significantly lower lateral root dry weight (67\%) and root to shoot ratios (23\%) than control seedlings (Table 2). Similarly, other studies have noted that the 
Table 3 Mean percent increases (based upon initial sample) for HT, RCD, RV, number of FOLR, SDW, TRDW, LRDW, R:SDW and STNC, TRTNC, LRTNC, and WTTNC for stock type treatments (container and bare-root seedlings)

\begin{tabular}{lcc}
\hline & \multicolumn{2}{c}{ Stock type treatment } \\
\cline { 2 - 3 } & Container & Bare-root \\
\hline HT (cm) & $44 \%$ & $23 \%$ \\
RCD (mm) & $72 \%$ & $34 \%$ \\
RV (cm $\left.{ }^{3}\right)$ & $226 \%$ & $145 \%$ \\
FOLR & $113 \%$ & $120 \%$ \\
SDW (g) & $238 \%$ & $96 \%$ \\
TRDW (g) & $125 \%$ & $48 \%$ \\
LRDW (g) & $226 \%$ & $239 \%$ \\
R:SDW & $-29 \%$ & $-21 \%$ \\
STNC (mg) & $391 \%$ & $141 \%$ \\
TRTNC (mg) & $138 \%$ & $102 \%$ \\
LRTNC (mg) & $533 \%$ & $197 \%$ \\
WTTNC (mg) & $105 \%$ & $42 \%$ \\
\hline
\end{tabular}

$H T$ height, $R V$ root volume, $S D W$ shoot dry weight, $T R D W$ taproot dry weight, $L R D W$ lateral root dry weight, $R: S D W$ root to shoot dry weight ratio, STNC total non-structural carbohydrates of shoot, TRTNC total non-structural carbohydrates of taproot, LRTNC total non-structural carbohydrates of lateral root, WTTNC total nonstructural carbohydrates of whole tree

removal of leaf area decreased fine root production (Ruess et al. 1998) or increased root mortality (Eissenstat and Duncan 1992). Reduction in root growth of newly planted seedlings may contribute to transplant stress and potentially result in mortality (Grossnickle 2005). Less leaf area associated with summer browsing may be caused by a lack of energy for leaf expansion; northern red oak seedlings have been observed to expend most of their stored TNC during the first flush (Kruger and Reich 1993). Removal of this new growth by browse or other mechanical injury forces seedlings to further deplete stored carbohydrates, principally from root systems in northern red oak (Sloan and Jacobs 2008). Correspondingly, summer-browsed seedlings showed negative percent increases for TNC in tap and lateral roots (Table 4), leading to significantly lower wholetree TNC than summer-browsed or control seedlings (Table 2).

Though summer-browsed seedlings were smaller than control and dormant-browsed seedlings, they had significantly higher gas exchange rates (Fig. 1). A reduction in leaf area for summer-browsed seedlings suggests an increased ratio of root absorption to leaf area, but the significantly smaller root to shoot ratios and lower lateral root dry weights (Table 2) of summer-browsed seedlings do not support the inference of Kruger and Reich (1993) that higher root to shoot ratios account for increased photosynthetic rates. Tschaplinski and Blake (1989b) found that increased sink demand may also play a role in higher photosynthetic rates of summer-browsed seedlings. When photosynthetic rates were expanded to a whole-tree basis, summer-browsed seedlings did not significantly differ from the other browse treatments due to a reduced leaf area (Table 2). A decreased leaf area and less time with mature leaves are likely causes of reduced growth and TNC content of summer-browsed seedlings.

In contrast to results observed for summer browsing, dormant browsing did not influence seedling morphology and physiology (Table 2; Figs. 1 and 2). Removal of the terminal bud cluster resulted in the loss of only nominal amounts of TNC content; lateral buds flushed to replace leaves that would have emerged from the terminal bud cluster. However, removing the terminal bud cluster did not produce significantly greater leaf area associated with release from apical dominance (Table 2), indicating little change from control seedlings in root to shoot ratios and/or sink demand.

\section{Conclusions}

This study demonstrated the effects of varying stock types and simulated browsing on northern red oak seedling physiological development and growth allocation. Contrary to our original hypothesis, we detected little evidence of increased resistance to herbivory stress in container stock.

Table 4 Mean percent increases (based upon initial sample) for HT, RCD, RV, number of FOLR, SDW, TRDW, LRDW, R:SDW and STNC, TRTNC, LRTNC, and WTTNC for seedlings subjected to three simulated browse treatments (control, dormant, and summer)

\begin{tabular}{lrrr}
\hline & \multicolumn{2}{c}{ Browsing treatment } & \\
\cline { 2 - 4 } & Control & Dormant & Summer \\
\hline HT (cm) & $35 \%$ & $34 \%$ & $13 \%$ \\
RCD (mm) & $55 \%$ & $55 \%$ & $34 \%$ \\
RV (cm $\left.{ }^{3}\right)$ & $207 \%$ & $192 \%$ & $82 \%$ \\
FOLR & $170 \%$ & $144 \%$ & $41 \%$ \\
SDW (g) & $93 \%$ & $96 \%$ & $38 \%$ \\
TRDW (g) & $21 \%$ & $75 \%$ & $21 \%$ \\
LRDW (g) & $445 \%$ & $213 \%$ & $78 \%$ \\
R:SDW & $-15 \%$ & $-31 \%$ & $-33 \%$ \\
STNC (mg) & $175 \%$ & $145 \%$ & $83 \%$ \\
TRTNC (mg) & $34 \%$ & $9 \%$ & $-20 \%$ \\
LRTNC (mg) & $653 \%$ & $200 \%$ & $-25 \%$ \\
WTTNC (mg) & $85 \%$ & $70 \%$ & $2 \%$ \\
\hline
\end{tabular}

$H T$ height, $R V$ root volume, $S D W$ shoot dry weight, TRDW taproot dry weight, $L R D W$ lateral root dry weight, $R: S D W$ root to shoot dry weight ratio, STNC total non-structural carbohydrates of shoot, TRTNC total non-structural carbohydrates of taproot, LRTNC total non-structural carbohydrates of lateral root, WTTNC total nonstructural carbohydrates of whole tree 
The more rapid growth rates relative to initial size and improved physiological status (i.e., higher photosynthetic rates) of container seedlings we observed did not produce significant interactions with browsing treatments. This may have been associated with the relatively well-watered conditions of this controlled greenhouse trial; responses may vary under exposure to moderate to severe drought, which represents a potential caveat when extrapolating these results to field conditions. Our second hypothesis that season of herbivory would cause variable seedling responses, however, was confirmed, but results were equally applicable across stock types. Although simulated summer browsing promoted generally higher photosynthetic rates, this was insufficient to overcome leaf area reductions. These seedlings, therefore, had lower biomass and TNC content than control or dormant-browsed seedlings. Summerbrowsed seedlings showed evidence of recovery of TNC concentrations, suggesting that growth may improve the following year in the absence of additional browsing. Sustained browsing through several growing seasons, however, will further deplete TNC stores and impair seedling capacity to compete with vegetation for above- and belowground resources, thereby reducing growth and likely increasing mortality (Canham et al. 1994; Morrissey et al. 2008). Our data helps illustrate the physiological basis for justification of browse protection of northern red oak seedlings in areas of high herbivore populations to help ensure successful regeneration.

Acknowledgments The Frederick M. van Eck Foundation of the Hardwood Tree Improvement and Regeneration Center and the Department of Forestry and Natural Resources at Purdue University contributed financial support. Gilbert Aussenac and two anonymous reviewers provided constructive feedback that improved the manuscript.

\section{References}

Andersen L, Rasmussen HN, Brander PE (2000) Regrowth and dry matter allocation in Quercus robur L. seedlings root pruned prior to transplanting. New For 19:205-213

Berström R, Danell K (1995) Effects of simulated summer browsing by moose on leaf and shoot biomass of birch, Betula pendula. Oikos 72:132-138

Blake TJ, Sutton RF (1987) Variation in water relations of black spruce stock types planted in Ontario. Tree Physiol 3:331-344

Borchert R (1975) Endogenous shoot growth rhythms and indeterminate shoot growth in oak. Physiol Plant 35:152-157

Burdett AN (1990) Physiological processes in plantation establishment and the development of specifications for forest planting stock. Can J For Res 20:415-427

Canham CD, McAninch JB, Wood DM (1994) Effects of the frequency, timing, and intensity of simulated browsing on growth and mortality of tree seedlings. Can J For Res 24:817-825

Carpenter LT, Pesenshki SR, Sheilds FD Jr (2008) Responses of nonstructural carbohydrates to shoot removal and soil moisture treatments in Salix nigra. Trees 22:737-748
Casabon C, Pothier D (2007) Browsing of tree regeneration by whitetailed deer in large clearcuts on Anticosti Island, Quebec. For Ecol Manage 253:112-119

Chow PS, Landhausser SM (2004) A method for routine measurements of total sugar and starch content in woody plant tissues. Tree Physiol 24:1129-1136

Cline MG (1997) Concepts and terminology of apical dominance. Am J Bot 84:1064-1069

Crawford HS (1982) Seasonal food selection and digestibility by tame white-tailed deer in central Maine. J Wildl Manage 46:974-982

Dey DC, Jacobs D, McNabb K, Miller G, Baldwin V, Foster G (2008) Artificial regeneration of major oak (Quercus) species in the eastern United States - a review of the literature. For Sci 54:77-106

Eissenstat DM, Duncan LW (1992) Root growth and carbohydrate responses in bearing citrus trees following partial canopy removal. Tree Physiol 10:245-257

Grossnickle SC (2005) Importance of root growth in overcoming planting stress. New For 30:273-294

Guehl JM, Aussenac G, Kaushal P (1989) The effects of transplanting stress on photosynthesis, stomatal conductance and leaf water potential in Cedrus atlantica Manetti seedlings: role of root regeneration. Ann For Sci 46:464-468

Guehl JM, Clement A, Kaushal P, Aussenac G (1993) Planting stress, water status and non-structural carbohydrate concentrations in Corsican pine seedlings. Tree Physiol 12:173-183

Hanson PJ, Dickson RE, Isebrands JG, Crow TR, Dixon RK (1986) A morphological index of Quercus seedling ontogeny for use in studies of physiology and growth. Tree Physiol 2:273-281

Healy WM (1971) Forage preferences of tame deer in a northwest Pennsylvania clear-cutting. J Wildl Manage 35:717-723

Horsley SB, Stout SL, de Calesta DS (2003) White-tailed deer impact on the vegetation dynamics of a northern hardwood forest. Ecol Appl 13:98-118

Irdis M, Salifu KF, Timmer VR (2004) Root plug effects on early growth and nutrition of container black spruce seedlings. For Ecol Manage 195:399-408

Jacobs DF (2003) Nursery production of hardwood seedlings. Purdue University Cooperative Extension Service. FNR 212:8

Jacobs DF, Ross-Davis AL, Davis AS (2004) Establishment success of conservation tree plantations in relation to silvicultural practices in Indiana, USA. New For 28:23-36

Jacobs DF, Salifu KF, Davis AS (2009) Drought susceptibility and recovery of transplanted Quercus rubra seedlings in relation to root system morphology. Ann For Sci 66:504

Johnson PS, Novinger SL, Mares WG (1984) Root, shoot and leaf area growth potential of northern red oak planting stock. For Sci 30:1017-1026

Johnson PS, Shifley SR, Rogers R (2002) The ecology and silviculture of oaks. CABI Publishing, New York

Kays JS, Canham CD (1991) Effects of time and frequency of cutting on hardwood root reserves and sprout growth. For Sci 37:524-539

Kosola KR, Dickmann DI, Paul EA, Parry D (2001) Repeated insect defoliation effects on growth, nitrogen acquisition, carbohydrates, and root demography of poplars. Oecologia 129:65-74

Kruger EL, Reich PB (1993) Coppicing affects growth, root:shoot relations and ecophysiology of potted Quercus rubra seedlings. Physiol Plant 89:751-760

McKay HM (1996) A review of the effect of stresses between lifting and planting on nursery stock quality and performance. New For 13:363-393

Morrissey RC, Jacobs DF, Seifert JR (2008) Response of northern red oak, black walnut and white ash seedlings to various levels of simulated summer deer browsing. In: Jacobs DF, Michler CH (eds) Proceedings, 16th Central Hardwood Forest Conference. USDA Forest Service Northeastern Research Station Gen. Tech. Rep. NRS-P-24: 50-58. 
Reich PB, Teskey RO, Johnson PS, Hinckley TM (1980) Periodic root and shoot growth in oak. For Sci 26:590-598

Ruess RW, Hendrick RL, Bryant JP (1998) Regulation of fine root dynamics by mammalian browsers in early successional Alaskan taiga forests. Ecology 79:2706-2720

Sloan JL, Jacobs DF (2008) Carbon translocation patterns associated with new root proliferation during episodic growth of transplanted Quercus rubra seedlings. Tree Physiol 28:1121-1126

Struve DK, Joly RJ (1992) Transplanted red oak seedlings mediate transplant shock by reducing leaf surface area and altering carbon allocation. Can J For Res 22:1441-1448

Tschaplinski TJ, Blake TJ (1989a) Photosynthetic reinvigoration of leaves following shoot decapitation and accelerated growth of coppice shoots. Physiol Plant 75:157-165

Tschaplinski TJ, Blake TJ (1989b) The role of sink demand in carbon partitioning and photosynthetic reinvigoration following shoot decapitation. Physiol Plant 75:166-173 van den Driessche R (1992) Absolute and relative growth of Douglasfir seedlings of different sizes. Tree Physiol 10:141-152

Wenny DL, Dumroese RK (1994) Nursery production: growing western white pine and western red cedar in greenhouses. In: Baumgartner DM, Lotan, JE, Tonn JR (eds) Proceedings, Interior Cedar-Hemlock-White Pine Forests: Ecology and Management, Washington State University Cooperative Extension, Pullman, pp. 261-266

Willaume M, Pages L (2006) How periodic growth pattern and source/ sink relations affect root growth in oak tree seedlings. J Exp Bot 57:815-826

Wilson ER, Vitols KC, Park A (2007) Root characteristics and growth potential of container and bare-root seedlings of red oak (Quercus rubra L.) in Ontario, Canada. New For 34:163176

Zaczek JJ, Steiner KC, Bowersox TW (1996) Northern red oak planting stock: 6-year results. New For 13:175-189 